\title{
LAW AGAINST THE PEOPLE/THE EMPIRE STRIKES BACK ${ }^{1}$
}

\section{George E. Bisharat}

Emeritus Professor of Law, University of California Hastings College of the Law. George E. Bisharat was a trial lawyer for the Office of the Public Defender in San Francisco before joining the UC Hastings faculty in 1991. Professor Bisharat studied law, anthropology, and Middle East studies at Harvard, and wrote a book about Palestinian lawyers working under Israeli military occupation in the West Bank. He writes frequently on the Middle East, both for academic audiences and for major media sources in the U.S. and abroad. After taking emeritus status in 2015, Bisharat, as "Big Harp George," has recorded two blues albums that earned award nominations and critical acclaim.

\section{SUMMARY}

The objective of this article is to describe and analyze how supporters of Israeli state policies have, since 2000, used legal forms often associated with efforts by the powerless to challenge entrenched power to instead turn those forms into tools of the powerful. This movement to use "law against the people" has come about largely as a reaction against attempts by activists to use courts and other legal fora to advance Palestinian rights. This unexpected boomerang effect provides reason for reflection on the role of law in the struggle for justice in Israel/Palestine, suggesting that law offers little promise of relief, at least when it is not integrated with and supported by a broader political strategy.

Key Words: Israel/Palestine; legal activism; human rights; international humanitarian law; lawyer.

This article is based on a lecture delivered September 10, 2015 at the Federal Fluminense University. 


\section{RESUMO}

O objetivo deste artigo é descrever e analisar como apoiadores das políticas estatais israelenses têm, desde 2000, usado formas jurídicas frequentemente associadas aos esforços dos destituídos de poder para desafiar o poder consolidado para, ao invés, torná-las ferramentas dos poderosos. Este movimento de uso da "lei contra o povo "surgiu em grande parte como uma reação contra as tentativas dos ativistas lançarem mão dos tribunais, e outros fóruns jurídicos, para a promoção dos direitos dos palestinos. Este inesperado efeito bumerangue fornece razões para reflexão sobre o papel do direito na luta pela justiça em Israel / Palestina, sugerindo que lei oferece pouca promessa de alívio, pelo menos quando não é integrada e apoiada por uma estratégia política mais ampla.

Palavras-chave: Israel / Palestina; ativismo legal; direitos humanos; direito humanitário internacional; advogado

The main goal of this brief article is to describe and analyze how supporters of Israeli state policies have, roughly since the year 2000 and the beginning of the Second Intifada ${ }^{2}$, used legal forms traditionally thought of

\footnotetext{
The term "intifada" means "uprising" or "overturning" in Arabic, and has been used to refer to two major waves of resistance to Israeli military occupation in the West Bank and Gaza Strip. The First Intifada commenced in late 1987 and persisted until approximately 1993 before trailing off, and involved mass demonstrations, tax resistance, strikes, and other forms of mostly unarmed resistance. The Second Intifada broke out in October 2000, sparked by a visit by Ariel Sharon, then candidate for Israeli prime minister, to the al-Aksa Mosque in Jerusalem, escorted by a heavily armed police contingent. Sharon's visit was interpreted as a symbolic assertion of Israeli sovereignty over the mosque and surrounding area, Islam's third most holy site. The al-Aksa Intifada, as it is also often called, quickly devolved into more militarized skirmishes, in which the Israeli army employed the fullness of its military arsenal against lightly armed Palestinian forces. The al-Aksa Intifada also witnessed the frequent resort by some Palestinian resistance groups of suicide bombings. This second uprising was quelled and again petered out inconclusively by 2006.
} 
as tools of the powerless against entrenched power, to instead defend and advance those state policies - or in other words, to use "law against the people." I add "The Empire Strikes Back"4 part to the title because for the most part, Israel's appropriation of what many may have thought were exclusively progressive legal instruments, doctrines, and organizational forms has been a response to Palestinians' and others earlier attempts, beginning in the late seventies to early eighties, to deploy legal strategies to achieve Palestinian goals, particularly via the framework of human rights. In other words, what I am describing here was a primarily reaction to, or retaliation against, Palestinians' attempts to mobilize law to their benefit. Indeed, Israel's supporters have coined a term, or at least borrowed one, to describe pro-Palestinian legal efforts. That term is "lawfare" - like warfare but replacing "war-" with "law-" - and that is how they see such efforts. We will return to this term and concept later. But that is why I describe it as "the empire striking back," invoking, of course the famous Star Wars movie.

\section{Introduction}

This reference may seem comedic and therefore inappropriate. After all, there is much human suffering in the subject of this article, and by no means do I intend to make light of it. But there is, at least, an element of irony in the fact that we - and I mean by that, supporters of Palestinian rights, including me - were the ones to introduce law to our struggle. Now we find ourselves possibly being beaten at our own game.

This article can be seen as a sequel to two interventions I have offered in Brazil previously: a lecture I offered in 2010 in the annual meeting of the Brazilian Anthropological Association in Belem and a subsequent article, both

\footnotetext{
Here I must recognize my intellectual debt to Jeff Halper, and particularly his monograph War Against the People. While the topic of Halper's study is different: that is, how Israeli employs "security politics" via the sale of arms and security technology to overcome its increasing isolation within the international community, essentially exporting means to wage "war against the people" globally, I was reading the book shortly before developing the thoughts reflected here and doubtless the title was in the back of my mind and led me to the parallel "law against the people."

4 http://www.imdb.com/title/tt0080684/
} 
entitled "Violence's Law"; and a lecture I offered in several Brazilian universities in 2014 entitled "Entrancement, Engagement, Estrangement: Three Moods in the Legal Struggle for Justice in Palestine/Israel." I begin by briefly recapping the arguments in these two interventions before turning to a brief sampling the work of three pro-Israel NGO's: Shurat Hadin, or the Israel Law Center; Regavim, which means "small pieces of land"; and The Lawfare Project. In my conclusion, I will suggest that the relative successes of these three groups in promoting Israeli state policies indicates that not only does law overwhelmingly favor power over justice, but that there are few or no "safe harbors" in procedural or substantive law that protect the powerless. Even the legal tools that have been specifically designed to protect the disenfranchised and downtrodden can be turned against them as weapons of oppression.

\section{Violence's Law}

In Violence's Law I reviewed Israel's campaign, beginning in the year 2000 , to deliberately violate certain principles of international humanitarian law (IHL) in the hope that their practices would ultimately be accepted as new norms of customary international law. These violations generally involved the principle of distinction that is a key part of IHL, which limits the circumstances in which military forces may inflict harm on civilian bodies and property. The principle of distinction holds that militaries must only target combatants - other soldiers or civilians directly engaged in fighting - and may only attack other civilian persons or objects when doing so confers a distinct military advantage.

Israel's purported innovations - such as the categorizing of civilian employees of the Hamas government in the Gaza Strip as members of a "terrorist organization," and therefore combatants subject to attack - would, if accepted, expand the scope of permissible violence. This, I asserted, would transform IHL from a body of law restricting violence to a body of law authorizing expanded violence - figuratively turning IHL on its head.

\footnotetext{
5 “A Lei da Violência". Antropolitica, n.30, 1sem.2011

6 UFF-InEAC, UnB; PUC/Porto Alegre
} 
This article may be thought of as a sequel to Violence's Law in sense that it puts Israel's attempts to transform international humanitarian law (IHL) to expand, rather than limit, its uses of extreme military power in the Gaza Strip into a wider context, and shows it to be just one facet of a broader phenomenon - that broader phenomenon being the inversion of law intended to protect the powerless in such a way as to authorize, expand, and legitimate the exercise of power.

\section{Enchantment, Engagement, and Estrangement}

This article is a sequel to the author's Entrancement, Engagement, and Estrangement lecture in the sense that it helps to complete a historical chronology. That lecture commenced with a discussion of a period of "enchantment" with law, covering, roughly, the 1980's, in which Palestinians, along with many others in various parts of the world, experienced their "human rights moment." This was a period in which human rights discourse became a prominent feature of the Palestinian struggle for justice. In Palestine and elsewhere, this work carried forward by new organizational expression, the human rights non-governmental organization, or NGO. I described my experience working with al-Haq, the first Palestinian human rights NGO in the early eighties. ${ }^{7}$

I can testify personally to the palpable sense of excitement, purpose, and vast scope of possibilities for work and action held by Palestinian rights activists at the time. The emergence of al-Haq coincided with, and was local expression of worldwide rise of human rights discourse and attendant burgeoning of human rights NGO's. Importantly, movement eventually generated - especially with the outbreak of the first Palestinian intifada or uprising in late 1987 - a plethora of NGO's promoting Palestinian human rights. Some were founded by and based in the Palestinian community, while others were based in Israel founded either by Palestinian citizens of that state or by Jewish Israelis. ${ }^{8}$

The organization was founded in 1979 in the West Bank town Ramallah, and continues in operation today. http://www.alhaq.org/

8 Adalah, for example, is an organization based within Israel that was founded in 1996 that continues in operation today. https://www.adalah.org/en 
Enchantment with the promise of law naturally led supporters of Palestinian rights and Palestinians themselves to legal engagement, mainly in the form of human rights documentation and reporting, especially focusing on Israel's violations in the Occupied Palestinian Territories (OPTs), but also extending to litigation in courts both within Israel itself and in the OPTs. Lawyers challenged a range of Israeli practices, from home demolitions, torture, restrictions on movement, banishments, land confiscations, Israel's separation wall, and more.

The upshot of both efforts, human rights documentation/reporting on the one hand, and litigation on the other hand, was the compilation of a voluminous record of Israeli violations, but virtually no alteration of Israeli practices, which are, if anything, increasing in severity and mounting in frequency. Over the years, lawyers for Palestinian rights have achieved a few qualified victories. But for every "victory", rights activists have suffered tens, if not scores, of losses. Particularly within Israel itself, unsuccessful challenges have often had the effect of legalizing those practices, at least for purposes of local law. Meanwhile, human rights NGO's in the OPTs have been routinized, bureaucratized, and domesticated by support from external donors, such as the European Union, who are more concerned to monitor the performance of the Palestinian Authority than they are to contest Israeli human rights violations. ${ }^{9}$ Thus the current period of estrangement from law, and cynicism about human rights discourse.

Unfortunately, this article will demonstrate that the reasons for this cynicism and estrangement are not just the relative failures of the human rights complex seeking to vindicate Palestinian rights. Indeed, the picture is far worse - that is to say, the reasons for cynicism and estrangement far greater - when we add to the balance not just the losses suffered by supporters of Palestinian rights and interests, but also the successes of those supporting Israeli state policies.

Let us now turn to those groups seeking to advance Israeli's interests.

$9 \quad$ Lori Allen, The Rise and Fall of Human Rights: Cynicism and Politics in Occupied Palestine, 2013. 


\section{Shurat Hadin}

Shurat Hadin ("the letter of the law") was established in Tel Aviv in 2003. According to its own web site, the group is modeled after the highly respected Southern Poverty Law Center, which was founded in Montgomery Alabama in 1971 with the objective of using civil litigation to combat racist organizations such as the Klu Klux Klan. Shurat Hadin describes itself as a legal defender of Israel and of Jewish interests internationally, and one of its slogans is that it "bankrupting terror one lawsuit at a time." It uses civil litigation (that is, not public prosecution) in courts throughout the world to combat "lawfare "- a term popularized among pro-Israel groups to depict Palestinians' attempts to mobilize law to advance their rights - which they see as a perversion or manipulation of human rights law to attack Western democracies, of which Israel is one. Shurat Hadin frequently initiates suits in the United States, typically partnering with U.S. law firms who actually carry out the litigation.

Some of its legal actions seem, frankly, frivolous, and designed merely to harass and take a toll (in time and money for legal defense, in reputation, in emotions) on critics of Israel so as to deter them from future criticism. For example, Shurat Hadin sued former President Jimmy Carter and Simon and Shuster, the publishers of Carter's 2006 book Palestine: Peace Not Apartheid, which argued that Israel would become an apartheid state if it did not grant freedom to Palestinians in the form of a sovereign state. The class action suit, brought in 2011 on behalf of five named plaintiffs and all purchasers of the book, alleged, in essence, that President Carter and Simon and Shuster had committed fraud against book purchasers in advertising the book as a work of non-fiction. The suit has, apparently, gone nowhere.

Sometimes its legal actions are very much more serious, such as a case that went to jury trial in early 2015 in federal court in New York. The suit had been filed against the Palestine Liberation Organization (PLO ) and Palestinian Authority (PA) seeking damages for injuries and deaths to American citizens caused by attacks during Second Intifada. The trial resulted in favorable verdict for the plaintiffs, and a judgment in amount of \$655 million dollars was ordered. Interestingly, the court relied on a form of extraterritorial jurisdic- 
tion that had previously been used by left-liberal groups within the U.S. to sue former officials of right wing regimes in Latin America for torture and other crimes against their peoples. The right typically is suspicious of this kind of extraterritorial jurisdiction, because they fear reciprocal prosecutions of U.S. officials abroad for our endless meddling in the internal affairs of other countries.

The jury verdict was overturned on jurisdictional grounds in August of 2016 by a U.S. court of appeals. But even to achieve the jury trial verdict is a huge success, in striking contrast to attempted suits by Palestinians in US courts which have been thrown out of court at very early stages of litigation on procedural grounds.

\section{Regavim}

"Regavim" means "small bits of land," a reference to a Zionist poem that promises the "redemption" of the land of Israel to Jewish sovereignty in piecemeal fashion. ${ }^{10}$ The organization was founded in Jerusalem in 2006, describing its objectives as protecting the lands of Israel from illegal encroachment both within Israel itself and in the territories Israel has occupied since 1967 (of course, without using that language). Regavim receives much of its funding from municipal councils of Israeli settlements and styles itself as a human rights NGO for Israeli settlers.

According to Perugini and Gordon, Regavim "mirrors" - or one might say mimics - the human rights discourse, organizational form, methods of evidence gathering, and bodies of law (such as environmental law) of left-oriented Israeli NGO's such as Yesh Din, which works to end Israeli occupation of the OPTs, including, prominently, expansion of Israeli settlements there. ${ }^{11}$ Regavim, in contrast, engages in advocacy and litigation to defend Israeli settler interests, both in the sense of fighting challenges to the legality of particular Israeli settlements (while all Israeli settlements in the OPTs are illegal under international law, according to the view of virtually the entire

\footnotetext{
${ }^{10}$ http://www.jns.org/latest-articles/2013/6/9/amid-global-focus-on-jewish-construction-ngocounters-illegal-arab-building\#.WUCGU7U_l-g=

11 Nicola Perugini and Neve Gordon, The Human Right to Dominate, 2015.
} 
international community, Israel itself distinguishes between "legal" settlements - those founded with direct support and authorization from the state - and "illegal" settlements - those founded through the private initiatives of typically religious nationalist Israeli settler individuals) and in encouraging Israeli authorities to demolish structures built by Palestinians without permits and which are, nominally, illegal. Israeli authorities have commonly used zoning laws, environmental regulations, wildlife preservation programs, and other regulations to severely limit expansion of Palestinian residency, both within Israel itself and in the OPTs. Palestinians desperate to build space for growing families and economic enterprise have frequently been forced to build without official permits, putting them at risk, and not uncommonly the actuality, of home and other building demolitions.

Regavim has experienced consistent successes in defending the interests of settlers, gaining official recognition for settlements originally founded without state approval, and pushing government agencies to enforced regulations limiting Palestinian land use. Indeed, in one case initiated against an "illegal" Israeli settlement by Yesh Din, that resulted in a court ruling in favor of the settlers, Regavim reportedly sent Yesh Din staff a bouquet of flowers in gratitude! ${ }^{12}$

\section{The Lawfare Project}

The Lawfare Project (TLP) was founded in New York City in 2010. It describes itself as the legal arm of the pro-Israel community and as a legal think tank that sponsors litigation and other legal action to protect civil and human rights of the "pro-human rights and counterterrorism communities." As the name implies, its particular preoccupation is fighting what it calls "lawfare" - the abuse of law as a weapon of war against Western democracy. It pays to remember that TLP came into being in the aftermath of a series of legal actions against a number of Israeli officials for war crimes in Belgium, Spain, the United Kingdom, and elsewhere.

12 Perugini and Gordon, ibid. 
The notion of "lawfare" is associated with the concept of asymmetric warfare, and the argument that the current global war on terror entails unprecedented and distinct strategic challenges for Western democracies. Asymmetric warfare involves confrontation between the regular armed forces of states,and the irregular forces of terrorists. The forces are asymmetrical not only in their scale - large state armies versus small bands of terrorists - but also in their respective tactics, weaponry, and adherence or non-adherence to prevailing norms and legal principles governing armed conflict. Armies are law-abiding, while terrorists are law-flouting, at least in conducting their own military operations. But they - terrorists and their sympathizers - are not above using law as a means to limit the combat capabilities of conventional armies, thus unfairly "weaponizing" law in the struggle against legitimate democratic governments. ${ }^{13}$ The Lawfare Project was founded, therefore, as a counterforce against efforts to shackle Western democracies - counting Israel, despite its geographic location, as one - in their unified fight against global terrorism.

TLP has engaged in a variety of actions, but devotes itself mostly to research and briefings. For example, the group generated a legal analysis of the refusal of Kuwait Airways to transport Israeli nationals under U.S. anti-discrimination law, which bars differential treatment based on such categories as ethnicity, race, or national origin, and then shared it with the U.S. Secretary of Transportation. He, apparently adopting the project's legal reasoning, ordered Kuwait Airways to abide by U.S. law or risk the termination of its leases at several U.S. airports. Kuwait Airways suspended its flights to the U.S. in response. ${ }^{14}$

TLP also campaigned to prevent broadcasting by Hamas and Hizbollah associated TV stations in the U.S., presenting domestic law enforcement

\footnotetext{
13 The originator of this term was Major General Charles Dunlap, USAF. See Lawfare Today, http:// scholarship.law.duke.edu/cgi/viewcontent.cgi?article=5892\&context=faculty_scholarship \&sei-redir $=1 \&$ referer $=$ http $\% 3 \mathrm{~A} \% 2 \mathrm{~F} \% 2 \mathrm{Fwww}$.bing.com\%2Fsearch\%3Fq\%3Dcharles\%2520dunlap\%2520lawfare\%26pc\%3Dcosp\%26ptag\%3DC1N0015D011214A316A5D3C6E\%26form\%3DCONBDF\%26conlogo\%3DCT3210127\#search=\%22 charles\%20dunlap\%20lawfare\%22

14 See http://thelawfareproject.org/advocacy/
} 
agencies a memorandum arguing potential criminal liability of those stations for illegal operations.

Perhaps the TLP's most significant accomplishments to date involve its work against the Palestinian/international movement for boycotts, divestment, and sanctions (BDS). The Palestinian BDS movement commenced in an organized and concerted fashion in 2005, one year after the International Court of Justice's (ICJ) advisory opinion finding the Israeli separation wall being built in Palestinian territory to be in violation of international law and ordering its dismantlement. No effective action had been taken by any government to comply with the ICJ's judgment, thus the BDS movement called for international solidarity among citizens of the world in support of rights of Palestinians to freedom, justice, and equality. ${ }^{15}$ In recent years the BDS movement has gained significant support among unions, professional associations, and student groups in Europe and the United States, and has been cited by Israeli authorities as a "strategic threat" and part of an effort to "delegitimize" Israel.

Along with other allies, The Lawfare Project has mounted campaigns in most of the fifty U.S. states and has persuaded some 26 to issue legislation or executive orders barring BDS. Like its efforts against Kuwait Airways, the legislation that TLP has supported has been framed in terms of anti-discrimination law. For example, a law currently winding its way through the California state legislature would require any bid for a public state contract to certify that it does not engage in any unlawful discrimination under existing California civil rights law under threat of criminal prosecution. The reference is to the same body of law that was adopted originally to combat racial discrimination against African Americans, Latino Americans, and others.

\section{Summary and Conclusions}

To recap what we have catalogued here of the legal efforts of pro-Israeli forces, we have seen: 1) the use of international humanitarian law to expand the scope of violence against civilians; 2) the application of human rights

15 https://bdsmovement.net/ 
law, environmental law, and other bodies of substantive law to advance Israel's colonization of the West Bank; 3) the exploitation of procedural devices such as extraterritorial jurisdiction and class action suits used to attack Palestinian institutions; 4) organizational form and other technical aspects of human rights documentation mirrored by Israeli settlers; 5) the deployment of anti-discrimination principles in the attempt to defeat peaceful forms of Palestinian resistance to oppression; and 6) all to significantly greater impact than virtually anything the Palestinians or their supporters have been able to achieve in the legal sphere.

\section{What does this all mean? What are we to make of this?}

One strongly suggested conclusion here - which may seem obvious - is that it is much easier for groups in civil society to sail with the winds of current power and state authority than it is to sail against them. Consider Regavim: surely, it has differences with Israeli authorities over how to colonize Palestinian lands, but the fact of colonization has been clearly supported by all Israeli governments since 1967. Shurat Hadin, meanwhile, makes explicit its coordination with Israeli government, for example, in its recent $\$ 1$ billion lawsuit against Facebook for allegedly providing material support to Palestinian groups attacking American citizens. ${ }^{16}$

What is also strongly suggested, however, is that there is very little leverage in substantive or procedural law itself that the relatively powerless can mobilize to their benefit. While we are all probably accustomed to thinking of law as an instrument of power, some of us may have been comforted ourselves in thinking that there were corners of law, or pockets of law, that were "ours" - that were specifically for challenges to power by the powerless. In this case, Israel/Palestine, that seems not to be the case, as we see have seen these areas of refuge within the law turned against us - whether in consumer protection law or class action suits, both devices originally legislated to empower individuals to effectively confront mistreatment at the hands of

\footnotetext{
16 See https://972mag.com/israeli-government-lawfare-contractor-sues-facebook-for-1b/120621/
} 
large corporations, or anti-discrimination law devised to assist persecuted minorities achieve equality and justice, or principles of extraterritorial jurisdiction generated to apprehend and punish international war criminals.

Far more thought and analysis is due before firm conclusions can be drawn, still less any prescription for peoples seeking justice against overwhelming power in places other than Israel/Palestine. But one expression comes to mind: "Don't poke a sleeping beast with a short stick!" In calling for "more law," as some Palestinians, including this author, have, over time, we have now gotten what we asked for - but in a far less favorable form than we had hoped.

Our mistake may have been to trust a law disembodied from politics to imagine that law could compensate for political weakness. What we now may be learning is that there are no shortcuts for the powerless - law will not be our refuge - and our legal victories, if we ever achieve them, will only develop as we build political muscle through long and arduous struggle outside the legal system. In other words, courts will rule for us only when they must. 